\title{
Desain Prototipe Kompor Listrik Tenaga Surya
}

\author{
Hasyim Asyari, Umar, Angga Purna Irawan \\ Teknik Elektro \\ Fakultas Teknik Universitas Muhammadiyah Surakarta \\ Surakarta, Indonesia \\ Hasyim.Asyari@ums.ac.id
}

\begin{abstract}
Abstraksi- Pemakaian bahan bakar yang bersumber dari fosil setiap tahunnya mengalami peningkatan drastis seiring bertambahnya jumlah penduduk. Bahan bakar fosil semakin menipis stoknya sehingga para peneliti mengkaji penggunaan bahan bakar yang bersifat terbarukan, sebagai upaya mengganti bahan bakar fosil dan gas. Indonesia sendiri pemanfaatan energi terbarukan saat ini belum optimal dalam menunjang kebutuhan masyarakat. Salah satu energi terbarukan yang dapat dimanfaatkan yakni energi matahari yang akan diaplikasikan pada kompor listrik. Saat ini proses untuk memasak oleh masyarakat secara umum masih menggunakan bahan bakar fosil dan gas. Tujuan penelitian ini adalah mendesain prototype kompor listrik berbasis energi terbarukan berupa sel surya. Metode yang digunakan oleh dalam penelitian ini yakni mendesain kompor listrik yang tersusun atas 3 buah Glow plug dan sebuah kawat nikelin (berdiameter $1 \mathrm{~mm}$ ). Energi listrik yang digunakan sebagai sumber energi utama kompor tersebut berasal dari cahaya matahari yang dikonversi menjadi energi listrik oleh 4 buah panel surya dengan kapasitas masing-masing $120 \mathrm{Wp}$, panel teresbut yang disusun secara paralel. Pada pengujian kompor listrik tenaga surya digunakan untuk menggoreng telur. Hasil penelitian menunjukkan bahwa kompor listrik hasil desain dapat dimanfaatkan untuk menggoreng telur dengan waktu 4 menit, pada kondisi tegangan suplai sebesar $19 \mathrm{~V}$, arus yang mengalir $19.02 \mathrm{~A}$, suhu panasnya berkisar pada angka $60^{\circ} \mathrm{C}$.
\end{abstract}

Katakunci-Kompor Listrik, Photovoltaic, Glow plug, Nikelin

\section{Pendahuluan}

Sejak program konversi minyak tanah ke gas, saat ini mulai menemui permasalahan klasik yaitu melambungnya dana subsidi oleh pemerintah. Pemerintah membuat regulasi untuk menanggulangi melambungnya dana subsidi tersebut dengan pembatasan gas ukuran $3 \mathrm{~kg}$ dan memproduksi tabung $5 \mathrm{~kg}$ yang harganya non subsidi.

Direktur Pembinaan Hilir Direktorat Jenderal Minyak dan Gas Bumi (Migas) Kementerian Energi dan Sumber Daya Mineral (ESDM) mengatakan subsidi minyak tanah jauh lebih besar jika dibandingkan dengan subsidi gas elpiji. Oleh karena itu, peluncuran program konversi minyak tanah ke elpiji $3 \mathrm{Kg}$, mampu memberikan penghematan, besarnya penghematan mencapai Rp 197 triliun. Konversi minyak tanah ke gas sudah berjalan kurang lebih 10 tahun [1].
Saat ini konsumsi elpiji Indonesia mencapai 6,7 juta ton (baik yang subsidi maupun yang non subsidi). Konsumsi tersebut diperkirakan terus meningkat $13 \%$ per tahun. Untuk pasokannya berasal dari impor sebesar 4,3 juta ton, sedangkan sisanya dari dalam negeri. "Indonesia sebagai produsen dan konsumen, konsumsi elpiji 6,57 juta ton dan impornya 4,3 juta ton. Kenaikan konsumsinya $13 \%$ per tahun," [1].

Hal ini sedikit menyulitkan UKM yang masih menggunakan minyak tanah, salah satunya UKM batik tulis. Minyak tanah digunakan sebagai bahan utama kompor dalam melarutkan malam atau lilin dalam proses batik tulis dengan canting. Permasalahan tersebut mendorong untuk melakukan kajian pemanfaatan potensi alam yang sifatnya free untuk sistem pemanas, sebagai contoh sinar matahari, panas matahari.

Produksi batik dengan pengrajin 12 orang setiap bulan dapat memproduksi helai demi helai batik tulis untuk 360 potong baju. Produksi batik saat ini menurun karena kalah dengan batik cap atau printing. Penelitian ini dilakukan untuk pengganti bahan bakar kompor minyak menjadi kompor listrik dengan memanfaatkan sinar matahari menggunakan panel surya. Panel surya adalah alat pengkonversi panas menjadi listrik yang nantinya akan diterapkan pada kompor listrik sebagai pengganti kompor minyak, dalam penelitian ini perlu adanya rancang bangun kompor listrik tenaga surya. Penelitian penggunaan energi untuk memasak sebagian besar dipasok dari panel surya, sehingga perlu kajian yang lebih detail terkait material pemanas kompor listrik[2].

\section{BAB II StUdi PUStaKA}

Sistem terdiri dari dua pembakar yang sekaligus membutuhkan panel surya yang menyediakan tenaga sebesar $1.520 \mathrm{~W}$. Kumparan dirancang sesuai dengan rating daya. Ada dua set baterai asam timbal $48 \mathrm{~V}$ yang berbagi kekuatan dengan panel sel surya saat memasak di siang hari; baterai dibebankan oleh panel saat kompor tidak digunakan. Kontroler panas telah dipasang untuk memungkinkan pengguna mengatur panas, [3].

Penggunaan energi terbarukan dapat berkontribusi untuk pembangkit energi. Untuk mengatasi masalah ini, kompor 
listrik dikembangkan dan kemudian dilakukan percobaan dengannya dan akhirnya dianalisis untuk memeriksa kompatibilitasnya di pasar sebenarnya. Untuk kompor ini, energi fotovoltaik (PV) surya akan menyediakan energi listrik yang dibutuhkan untuk memasak [2].

Desain kompor listrik tenaga surya menggunakan 4 buah panel surya yang masing-masing berkapasitas $120 \mathrm{Wp}$, sedangkan pemanasnya digunakan glow plug. Pada pengujian untuk melelehkan material berupa lilin dengan berat 66 gram, kompor listrik tenaga surya membutuhkan waktu 6 menit dengan temperature $100{ }^{\circ} \mathrm{C}[4]$.

Glow plug dipasang di dalam ruang bakar / combustion chamber. Energi panas yang dihasilkan oleh glow plug di dapat dari arus listrik DC (Direct Current). Glow plug secara umum digunakan pada mesin-mesin berbahan bakar solar. Baik untuk konstruksi indirect ataupun direct injection, kehadiran glow plug tetap ada. Pada bagian indirect injection, glow plug diletakkan didalam pre-chamber. Untuk direct injection, glow plug diletakkan di combustion chamber secara langsung. Lewat arus yang diberikan oleh accu, glow plug akan menghasilkan panas didalam silinder. Sehingga lebih memudahkan mesin bekerja pada suhu kerja idealnya.

Prinsip kerja glow plug seperti heater elektrik yang memanfaatkan penumpukan elektron pada sebuah konduktor yang menyebabkan suhu pada konduktor tersebut meningkat. Peningkatan suhu ini juga tidak main main karena bisa mendidihkan air dengan cepat.

Kawat nikelin adalah kawat untuk elemen pemanas dengan arus listrik. Kawat ini biasa digunakan untuk elemen pemanas pada alat pemotong karet, stempel warna, alat pemotong plastik, stereofoam, dan alat seal plastik (alat penutup/pengemas plastik) dan masih banyak lagi kegunaannya. Kawat nikelin berfungsi untuk menyalurkan panas, sehingga kawat nikelin termasuk ke dalam bahan konduktor dan juga bahan yang dapat digunakan untuk mempercepat aliran panas pada suatu benda. Banyak orang menggunakan bahan konduktor untuk memindahkan panas dengan cepat. Selain itu juga untuk mendinginkan benda dengan lebih cepat. Contoh penggunaan kawat nikelin bisa dilihat pada lilitan radiator di bagian belakang lemari es yang terbuat dari tembaga. Hal itu dikarenakan agar panas yang dihasilkan dapat cepat dialirkan dari lemari es (refrigerator) menuju keudara sekitar. Peralatan masak seperti panci dan penggorengan dibuat dari aluminium, baja atau teflon, dengan demikian, panas dapat dialirkan dengan cepat dari api ke masakan.

\section{Bab tiga Metode Penelitian}

Penelitian ini terdiri dari beberapa tahapan, yaitu: tahap perencanaan desain alat (penggunaan jenis pemanas, mendesain fisik kompor), perakitan (pemanas, fisik kompor dan panel surya). Tahap berikutnya adalah pengujian sistem kompor listrik tenaga surya.

Tahap perencanaan ini merupakan tahap melakukan perancangan desain meliputi perancangan model alat yang sederhana dan sesuai, perancangan model alat dan perancangan komponen yang akan digunakan.

Tahap persiapan alat dan komponen, tahapan ini peralatan yang digunakan yaitu, las listrik, bor, obeng, tang multimeter. Sedangkan komponen yang digunakan panel surya, Glow plug, saklar, kawat nikelin dan komponen lainnya.

Tahap pengujian merupakan tahapan yang dilakukan setelah sistem terinstal di lokasi (panel surya, kompor listrik tenaga sel surya), dilanjutkan pengujian penggunaan alat secara langsung untuk memasak.

Diagram alir penelitian ditunjukkan pada gambar 1 .

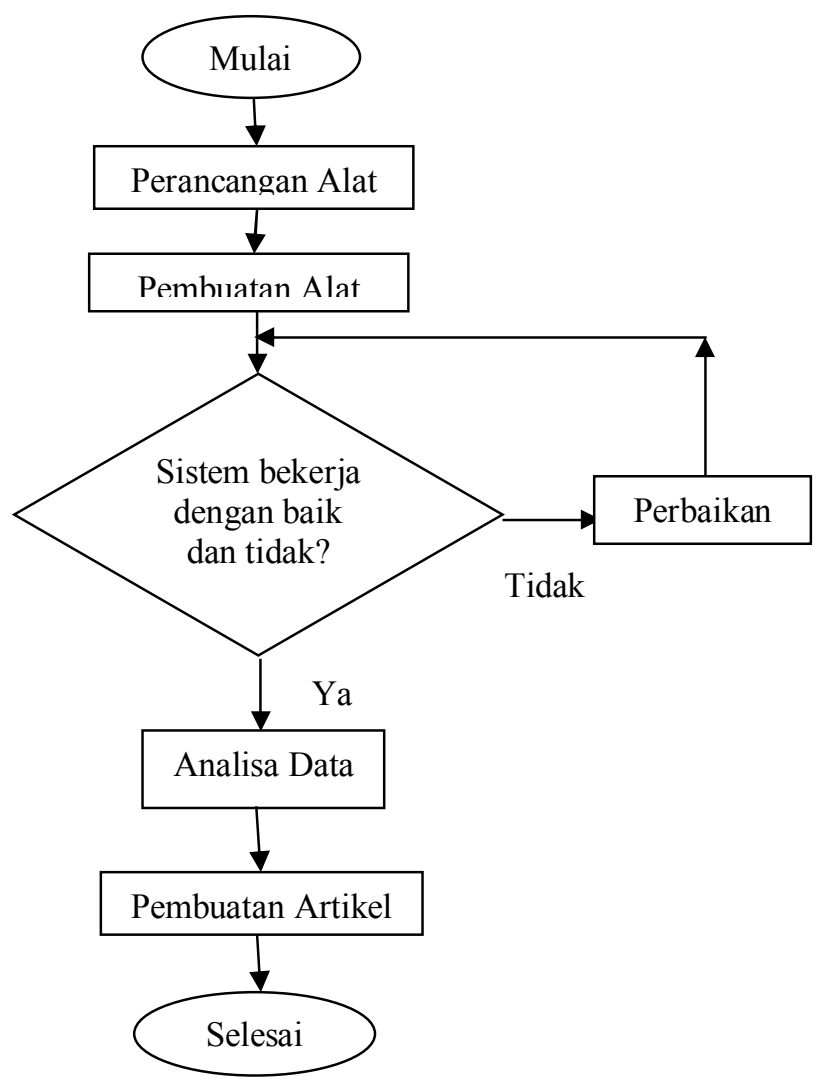

Gambar 1. Diagram Alir Penelitian

\section{BAB EMPAT HASIL DAN ANALISA PENELITIAN}

\section{A. Desian Kompor Listrik Tenaga Surya}

Desain kompor listrik pada penelitian ini menggunakan energi matahari sebagai sumber energi utamanya. Sinar matahari dikonversi atau diubah menjadi energi listrik oleh panel photovoltaic/panel sel surya. Energi listrik yang dihasilkan akan digunakan untuk mensuplai kompor listrik. Kompor listrik tersebut dengan memanfaatkan kawat nikelin dan glow plug akan mengkonversi energi listrik menjadi energy panas. Hasil desain kompor listrik tenaga surya dan komponen-komponen yang digunakan dalam penelitian ini ditunjukkan pada gambar 2, 3, 4, dan gambar 5 . 


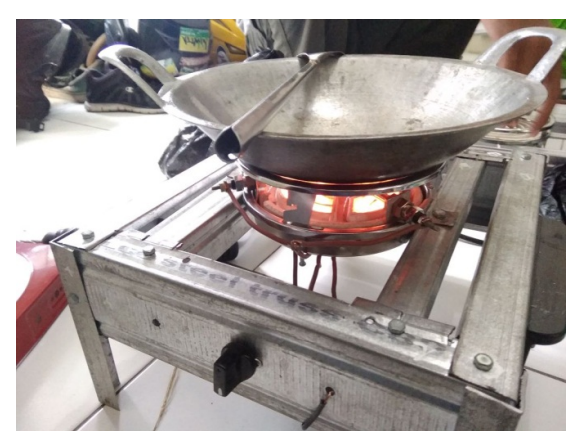

Gambar 2. Kompor listrik

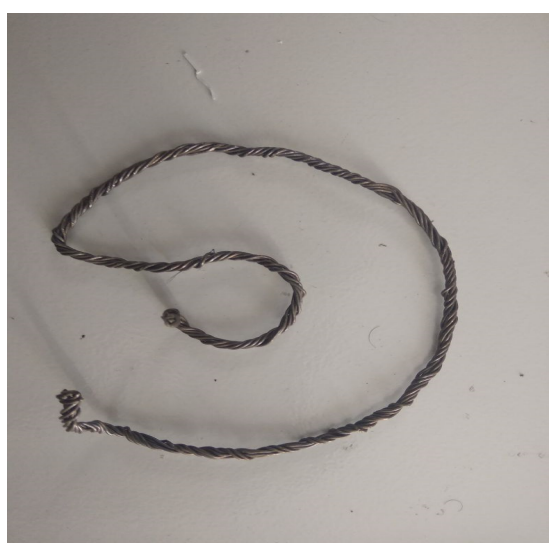

Gambar 3. Kawat Nikelin

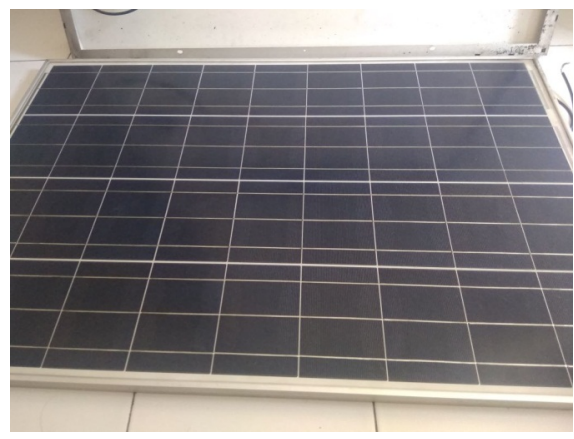

Gambar 4. Panel Surya

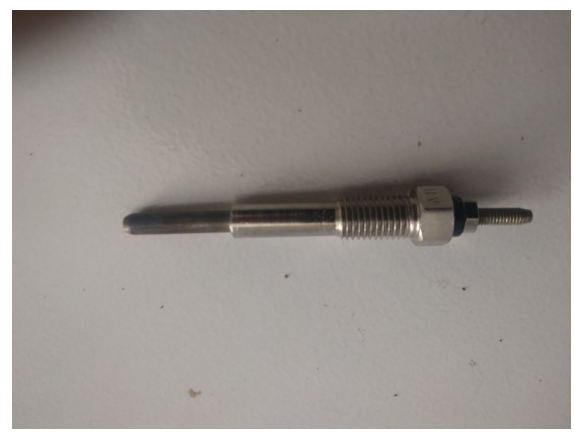

Gambar 5. Busi Pemanas Glow plug

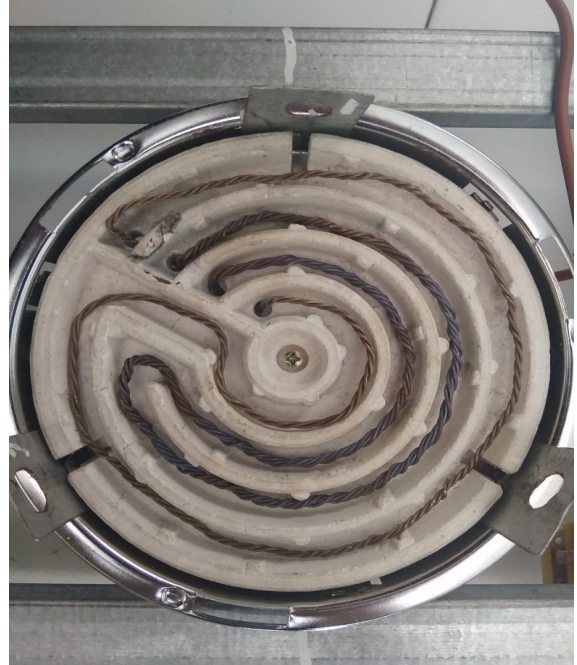

Gambar 6. Keramik Tumpuan Pemanas

\section{B. Hasil Pengujian Kompor Listrik Tenaga Surya}

Tabel 1. Hasil uji penggorengan telur dengan 1 panel surya

\begin{tabular}{ccccc}
\hline \hline $\begin{array}{c}\text { Posisi } \\
\text { Saklar }\end{array}$ & $\begin{array}{c}\mathrm{V}_{\mathrm{tb}} \\
(\text { volt })\end{array}$ & $\mathrm{I}(\mathrm{A})$ & $\begin{array}{c}\text { Suhu } \\
\left({ }^{\circ} \mathrm{C}\right)\end{array}$ & $\begin{array}{c}\text { Lama } \\
\text { Menggoreng }\end{array}$ \\
\hline Posisi 1 & $13.5 \mathrm{~V}$ & $3.63 \mathrm{~A}$ & - & - \\
\hline Posisi 2 & $18.3 \mathrm{~V}$ & $3.63 \mathrm{~A}$ & - & - \\
\hline \hline
\end{tabular}

Data pengujian yang ditunjukkan pada tabel 1 dapat diketahui bahwa saat menggunakan 1 buah panel saja yang berkapasitas $120 \mathrm{Wp}$ dan ketika saklar diputar ke posisi 1 seharusnya pemanas yang menyala yaitu 2 buah glow plug dan 1 jalur kawat nikelin. Ketika saklar diputar keposisi 2 seharusnya pemanas yang menyala yaitu 3 buah Glow plug dan 2 jalur kawat nikelin. Namun pada kenyataanya belum mampu menyalakan kedua buah pemanas tersebut. Hal ini disebabkan karena arus yang mengalir pada saat terhubung 1 panel saja daya yang dihasilkan lebih kecil dari yang unjuk kerja elemen pemanas kompor listrik tersebut.

Tabel 2. Hasil uji penggorengn telur dengan 2 panel surya

\begin{tabular}{ccccc}
\hline $\begin{array}{c}\text { Posisi } \\
\text { Saklar }\end{array}$ & $\begin{array}{c}\mathrm{V}_{\mathrm{tb}} \\
(\mathrm{volt})\end{array}$ & $\mathrm{I}(\mathrm{A})$ & $\begin{array}{c}\text { Suhu } \\
\left({ }^{\circ} \mathrm{C}\right)\end{array}$ & $\begin{array}{c}\text { Lama } \\
\text { Menggoreng }\end{array}$ \\
\hline Posisi 1 & 18.8 & 12.26 & 33.6 & 18 Menit \\
\hline Posisi 2 & 17.0 & 12.16 & 60.6 & 6 Menit \\
\hline \hline
\end{tabular}

Hasil dari pengujian tabel 2 bahwa saat menggunakan 2 panel surya pada saat saklar posisi 1, jumlah pemanas yang berfungsi adalah 2 buah Glow plug dan 1 jalur kawat nikelin, pada kondisi tersebut panel surya menghasilkan tegangan 
$18.8 \mathrm{~V}$, arus $12.26 \mathrm{~A}$ dengan suhu mencapai $33.6^{\circ} \mathrm{C}$ dan waktu untuk menggoreng telur selama 18 menit. Tetapi saat saklar pada posisi 2 , jumlah pemanas yang berfungsi adalah 3 buah Glow plug dan 2 jalur kawat nikelin yang disuplai dengan tegangan sebesar $17.0 \mathrm{~V}$, arus $12.26 \mathrm{~A}$. pada kondisi tersebut waktu yang dibutuhkan hanya 6 menit, dan suhu mencapai $60,6^{\circ} \mathrm{C}$.

Tabel 3. Hasil uji penggorengan telur dengan 3 panel surya

\begin{tabular}{ccccc}
$\begin{array}{c}\text { Posisi } \\
\text { Saklar }\end{array}$ & $\begin{array}{c}\mathrm{V}_{\mathrm{tb}} \\
(\mathrm{volt})\end{array}$ & $\mathrm{I}(\mathrm{A})$ & $\begin{array}{c}\text { Suhu } \\
\left({ }^{\circ} \mathrm{C}\right)\end{array}$ & $\begin{array}{c}\text { Lama } \\
\text { Menggoreng }\end{array}$ \\
\hline Posisi 1 & 19.8 & 15.73 & 49 & 10 Menit \\
\hline Posisi 2 & 19.9 & 16.73 & 60.6 & 6 Menit \\
\hline \hline
\end{tabular}

Hasil pengujian pada tabel 3 ini menggunakan 3 panel surya yang disusun secara parallel, pada saat saklar posisi 1 jumlah pemanas yang berfungsi adalah 2 buah glow plug dan 1 jalur kawat nikelin, elemen pemanasa disuplai dengan tegangan $19.8 \mathrm{~V}$, arus $15.73 \mathrm{~A}$, dengan suhu mencapai $49^{\circ} \mathrm{C}$ dan waktu menggoreng telur yaitu 10 menit. Saat saklar posisi 2 dengan jumlah pemanas yang berfungsi 3 buah Glow plug dan 2 jalur kawat nikelin, elemen pemanas disuplai tegangan $19.9 \mathrm{~V}$, arus $16.73 \mathrm{~A}$, dengan suhu mencapai $60,6^{\circ} \mathrm{C}$ dengan waktu menggoreng telur selama 6 menit.

Tabel 4. Hasil uji penggorengan telur dengan 4 panel surya

\begin{tabular}{ccccc}
\hline \hline $\begin{array}{c}\text { Posisi } \\
\text { Saklar }\end{array}$ & $\begin{array}{c}\mathrm{V}_{\mathrm{tb}} \\
(\mathrm{volt})\end{array}$ & $\mathrm{I}(\mathrm{A})$ & $\begin{array}{c}\text { Suhu } \\
\left({ }^{\circ} \mathrm{C}\right)\end{array}$ & $\begin{array}{c}\text { Lama } \\
\text { Menggoreng }\end{array}$ \\
\hline Posisi 1 & 18.9 & 19.02 & 48.6 & 7 Menit \\
\hline Posisi 2 & 19.0 & 19.02 & 60.6 & 4 Menit \\
\hline \hline
\end{tabular}

Hasil pengujian pada tabel 4 dapat diketahui bahwa pada saat menggunakan 4 panel surya dan saklar posisi 1 maka jumlah pemanas yang berfungsi adalah 2 buah glow plug dan 1 jalur kawat nikelin, tegangan yang terhubung dengan elemen pemanas terebut sebesar $18.9 \mathrm{~V}$, arus $19.02 \mathrm{~A}$, suhu $48.6^{\circ} \mathrm{C}$ dengan waktu penggorengan telur kurang lebih selama 7 menit. Pada saat saklar posisi 2, jumlah pemanas yang berfungsi adalah 3 buah glow plug dan 2 jalur kawat nikelin, sumber tegangan $19 \mathrm{~V}$, arus $19.02 \mathrm{~A}$, suhu $60.6{ }^{\circ} \mathrm{C}$ dengan waktu penggorengan telur kurang lebih selama 4 menit.

\section{BAB LIMA KESIMPULAN}

Berdasarkan hasil penelitian dapat disimpulkan bahwa :

1. Rancang bangun kompor listrik memanfaatkan 4 buah panel surya dengan berkapasitas setiap panel adalah 120 Wp sebagai sumber utama yang mengkonversi sinar matahari menjadi energy listrik. Kompor ini terbuat dari beberapa material bahan yakni Glow plug, kawat nikelin, panel surya, baja ringan dan isolator sebagai komponen utam, a pembuatannya.

2. Pada saat sumber tegangan $19 \mathrm{~V}$, arus $19,2 \mathrm{~A}$, alat ini dapat menggoreng telur dalam waktu 4 menit dan suhu panas bejana penggorangan pada suhu $60,6^{\circ} \mathrm{C}$.

\section{DAfTAR PUSTAKa}

[1] Setyo Rini, 2017, http://bisnis.liputan6.com/read/2829428/negara-hemat-rp-197-tberkat-konversi-minyak-tanah-ke-elpiji.

[2] Islam, Azad, Fakir, Rahman. 2014, Development of Electric Stove for Smart use of Solar Photovoltaic Energi with Nasional Gied. IEEE, pp. 94-98.

[3] Siddiqua, dkk, 2016, Development of Double Burner Smart Electric Stove Powered by Solar Photovoltaic Energi. IEEE, pp 451-458.

[4] Abdul Khamid, 2017, Desain Kompor Listrik Tenaga Surya unutk Batik Tulis yang Ramah Lingkungan, http://eprints.ums.ac.id/58616/5/Naskah\%20Publikasi.pdf. 